\title{
Interaction of Seedling Germination, Planting Date, and Flumioxazin on Peanut Physiology under Irrigated Conditions
}

\author{
Nicholas L. Hurdle, Timothy L. Grey, Cristiane Pilon, W. Scott Monfort, Donn G. Shilling \\ Department of Crop and Soil Sciences, University of Georgia, Tifton, GA, USA \\ Email: tgrey@uga.edu
}

How to cite this paper: Hurdle, N.L., Grey, T.L., Pilon, C., Monfort, W.S. and Shilling, D.G. (2020) Interaction of Seedling Germination, Planting Date, and Flumioxazin on Peanut Physiology under Irrigated Conditions. American Journal of Plant Sciences, 11, 2012-2030. https://doi.org/10.4236/ajps.2020.1112142

Received: November 2, 2020

Accepted: December 11, 2020

Published: December 14, 2020

Copyright $\odot 2020$ by author(s) and Scientific Research Publishing Inc. This work is licensed under the Creative Commons Attribution International License (CC BY 4.0).

http://creativecommons.org/licenses/by/4.0/

\section{(c) (i) Open Access}

\begin{abstract}
Diclosulam and flumioxazin applied preemergent (PRE) results in direct peanut exposure to these herbicides prior to seedling emergence. Flumioxazin has been reported to induce injury in adverse weather (i.e. cool-wet soil conditions) at crop emergence. Research at Ty Ty and Plains, Georgia evaluated the physiological effects of PRE herbicides to emerging peanut in 2018 and 2019. Peanut seed with variable germination and different planting dates were evaluated as additional factors. Peanut plant physiological measurements included electron transport (ETR), net assimilation rate $\left(A_{\text {net }}\right)$, quantum yield of PSII $\left(\Phi_{\text {PSII }}\right)$, and stomatal conductance to water vapor (GSW). Data were obtained from V3 to R1 peanut growth stages using a LiCOR 6800, along with stand counts and plant width measures. In 2018, diclosulam reduced peanut ETR when measured across multiple growing degree days (GDD) after planting, compared to the nontreated control (NTC). Flumioxazin reduced peanut ETR compared to the NTC, at several sample timings for each planting date. In 2018 and 2019 at both locations, flumioxazin impacted $A_{\text {net }}$ less than ETR, but was consistently similar to/or greater than the NTC. Peanut $\Phi_{\text {PSII }}$ responded similarly as $A_{\text {net }}$ at each location and yr. GSW was variable in both years; however flumioxazin treated plants had higher GSW rates than other treated plants. Peanut stand counts, plant widths, and pod yields noted few differences compared to the physiological measures. Though some peanut plant physiological differences were noted when measured at varying GDD's after planting with the different PRE treatments, planting date, and seed vigor, no specific trends were observed. Growers will often observe peanut injury from flumioxazin early in the season. However, it is transient and does not affect yield.
\end{abstract}

\section{Keywords}

Diclosulam, Flumioxazin, Peanut, Arachis hypogaea L., Photosynthesis, 


\section{Introduction}

In 2019, $85 \%$ of US peanut (Arachis hypogea L.) hectares were planted in the southeastern states of Alabama, Florida, Georgia, Mississippi, North Carolina, South Carolina, and Virginia [1]. Georgia leads the nation with $47 \%$ of production [2]. In order to maintain this profitability, peanut growers need to be able to start the growing season with high quality seed, establish an adequate population, under weed free conditions. Planting peanut at the optimal timing is critical in order to establish adequate populations. Factors such as soil temperature, air temperature, and soil moisture play an important role in acceptable stand establishment. Kvien et al. [3] indicated that adequate peanut germination will occur when soil temperatures are in the range of $20^{\circ} \mathrm{C}$ to $35^{\circ} \mathrm{C}$ at a depth of 10 $\mathrm{cm}$ for 3 consecutive days.

Peanut emerges from soil within 6 to 11 days after planting, depending upon soil and air temperatures [4]. Research has indicated optimal growing conditions occur between air temperatures of $27^{\circ} \mathrm{C}$ to $32^{\circ} \mathrm{C}$ [5]. These optimal germinating conditions typically occur between late April and May for southern Georgia, yet some varieties allow for early planting due to a resistance to Tomato spotted wilt virus (TSWV) (Family: Bunyaviridae Genus: Tospovirus) transmitted by the western flower thrip (Frankliniella occidentalis Pergande) and tobacco thrips (Frankliniella fusca Hinds) [6] [7] [8]. Prasad et al. [8] reported that cooler soil temperatures resulted in smaller seedlings and lower plant populations in peanut. These sub-optimal soil temperature conditions may also impact physiological factors in early season peanut growth.

Peanuts are very susceptible to competition from weeds as canopy closure occurs 8 to 10 weeks after planting, or not at all [9]. Optimal weed management includes beginning the peanut growing season weed-free using herbicides that allow the crop to become established without competition. Maintaining a weed free peanut crop from weeks 3 to 8 after planting is essential, allowing peanut to achieve a maximum yield [10]. Peanut growers typically apply PRE herbicides including pendimethalin, $S$-metolachlor, and flumioxazin [2]. In Georgia, PRE herbicides diclosulam and flumioxazin are often recommended [11]. Diclosulam, an ALS herbicide, has been used as a PRE herbicide in peanut since 2000 [12]. It has demonstrated excellent crop safety in Georgia [13] and has a POST label for Benghal dayflower (Commelina benghalensis L.) control. However, it has limited uses in some states due to peanut injury concerns [14] [15].

Since 2001, growers have been able to use flumioxazin herbicide for peanut weed control [16]. Flumioxazin is an $N$-phenylphthalimide and is classified as a PPO-inhibitor [17]. In a normal functioning chloroplast, protoporphyrinogen IX oxidase will oxidize protoporphyrinogen IX (PPGIX) into protoporphyrin IX 
(PPIX) to eventually become chlorophyll or cytochromes. Once a PPO-inhibiting herbicide is absorbed, the oxidation process will not occur, thus resulting in a buildup of PPGIX that will undergo extraplastidic oxidation [18]. After oxidation, the newly formed PPIX will begin absorbing light, resulting in the formation of radical singlet oxygen that will cause cell membrane and pigment destruction, tissue decay, and eventual plant death. Numerous studies have established that cotton (Gossypium hirsutum L.) and peanut may sustain injury after emergence from flumioxazin applications [19] [20] [21] [22] [23]. Berger et al. [19] indicated that flumioxazin applied 15-day PRE cotton planting at 30 and 60 $\mathrm{g} \cdot \mathrm{ha}^{-1}$ resulted in significant stand loss compared to the nontreated control at one location. Stand counts were reduced up to $71 \%$ compared to the nontreated control due to a higher rainfall amounts at that location. Johnson et al. [22] reported peanut injury symptomology included overall stunting, necrotic lesions, and discolored petioles in peanut. The investigators applied flumioxazin up to 10 days after planting (DAP) and noted visual injury 26 DAP was up to 59\%. Wilcut et al. [23] noted similar injury as Johnson et al. [22], in that flumioxazin symptomology included stunting and necrotic foliage, and also included delayed emergence. The investigators tested 8 Virginia type peanut cultivars and indicated that 7 were injured up to $28 \%$, and one $45 \%$. These investigators supported the claim by Berger et al. [19] that rainfall is a significant factor in crop injury.

In addition to large amounts of rainfall, cooler temperatures reduced plant metabolism, therefore intensifying crop injury [24]. English et al. [25] reported that as flumioxazin contacted the hypocotyl of developing peanut plants, lesions formed, which often prevented the cotyledon from opening, stunting seedling development, or becoming lethal to the plant. Though flumioxazin provides excellent early season weed control, under certain environmental conditions, flumioxazin will cause crop injury.

Though injury observed is transient and should not affect yield, physiological injury has not been measured in peanut. The purpose of this study is to quantify flumioxazin interactions in emergence, stand establishment, and measure photosynthetic efficiency analytically in leaves of peanut seedlings.

\section{Materials and Methods}

Peanut field experiments. Irrigated peanut field trials were conducted at the University of Georgia Ponder Farm near Ty Ty, GA (31.51 N, 83.65 W) and the Southwest Georgia Research and Education Center in Plains, GA (32.04 N, 84.38 W) in 2018 and 2019. Soil properties near Ty Ty consisted of 100\% Tifton loamy sand (Fine-loamy, kaolinitic, thermic Plinthic Kandiudults) with 25\% clay, 67\% sand, 9\% silt, and $0.3 \%$ organic matter in the 2018 location. The 2019 location consisted of Dothan loamy sand (Fine-loamy, kaolinitic, thermic Plinthic Kandiudults) and Fuquay loamy sand (Loamy, Kaolinitic, thermic Arenic Plinthic Kandiudults) for a soil composition of $22 \%$ clay, $70 \%$ sand, $8 \%$ silt, and $0.4 \%$ organic matter. The 2018 Plains location consisted of Faceville sandy loam (Fine, kaolinitic, thermic Typic Kandiudults), Ochlockonee local alluvium (Coarse-loamy, 
siliceous, acid, thermic Typic Udifluvents), and Tifton sandy loam (Fine-loamy, kaolinitic, thermic Plinthic Kandiudults) for a soil composition of $26 \%$ clay, $62 \%$ sand, $12 \%$ silt, and $0.4 \%$ organic matter. The 2019 location consisted of a Greenville sandy loam (clayey, kaolinitic, thermic Rhodic Kandiudults) and Tifton sandy loam (Fine-loamy kaolinitic, thermic Plinthic Kandiudults) for a composition of $35 \%$ clay, $57 \%$ sand, $8 \%$ silt, and $0.2 \%$ organic matter.

Experimental design was a split-split-plot with 4 replications. Main plots were PD to simulate one early planting and 2 on-time plantings. One subplot component was two different seed lots of Georgia 16HO peanut [26] with 75 (Low) and 90\% (High) germination rates (Georgia Seed Development Association, Athens GA), each yr. The second subplot component was herbicide treatments of flumioxazin at $107 \mathrm{~g} \cdot \mathrm{ai} \cdot \mathrm{ha}^{-1}$ [27], diclosulam at $27 \mathrm{~g} \cdot \mathrm{ai} \cdot \mathrm{ha}^{-1}$ [28] and a nontreated control (NTC). Herbicide treatments were applied immediately after planting using TeeJet (TeeJet, Wheaton, IL) AIXR 11002 nozzles at $187 \mathrm{~L} / \mathrm{ha}$ at $207 \mathrm{kPa}$. Herbicides were irrigated within $3 \mathrm{~d}$ of application to ensure proper herbicide movement into the soil if no rainfall had occurred. Planting dates in Ty Ty were April $9^{\text {th }}$, April $25^{\text {th }}$, May $8^{\text {th }}$; and April $12^{\text {th }}$, April $25^{\text {th }}$, May $9^{\text {th }}$, respectively for 2018 and 2019. Planting dates for Plains were April $20^{\text {th }}$, May $3^{\text {rd }}$, May $14^{\text {th }}$; and April $17^{\text {th }}$, May $1^{\text {st }}$, May $14^{\text {th }}$, respectively for 2018 and 2019 . Weather data for each location across the entire study are in Table 1 . The Plains location was planted in a single-row manner at 18 seed $\mathrm{m}^{-1}$ of row while Ty Ty was planted at 18 seed $\mathrm{m}^{-1}$ in a twin row pattern [11]. All experiments received a blanket application of pendimethalin PRE applied at $1067 \mathrm{~g} \cdot \mathrm{ai} \cdot \mathrm{ha}^{-1}$. Plots at Ty Ty received an application of phorate insecticide applied at $2945 \mathrm{~g} \cdot \mathrm{ha}^{-1}$ both years. The Plains location received a POST treatment of dicrotophos insecticide at $140 \mathrm{~g} \cdot \mathrm{ha}^{-1}$. All plots were maintained weed-free and under University of Georgia agronomic recommendations [10].

Numerous steps of photosynthesis were measured using the infrared gas analyzer LiCOR 6800 (LiCOR Biosciences, Lincoln, NE). These included the physiological parameters of net photosynthesis assimilation $\left(A_{\text {net }}\right)$, electron transport efficiency (ETR), quantum yield of PSII $\left(\Phi_{\text {PSII }}\right)$, and stomatal conductance to water vapor, all of which were collected in this study. The LiCOR compares the mass flow per time of these gases and determines the net assimilation rate:

$$
A_{\text {net }}=\frac{\mu_{0}\left[c_{0}-c_{a}\left(\frac{1-\omega_{0}}{1-\omega_{a}}\right)\right]}{s}
$$

where $A_{\text {net }}$ represents net carbon assimilation, $\mu_{0}$ is the flow rate entering the leaf chamber, $c_{0}$ is the $\mathrm{CO}_{2}$ concentration entering the chamber, $\omega_{0}$ is $\mathrm{H}_{2} \mathrm{O}$ entering the chamber, $\mu_{a}$ is the flow rate of air leaving the chamber, $c_{a}$ is the $\mathrm{CO}_{2}$ concentration leaving the chamber, $\omega_{a}$ is the $\mathrm{H}_{2} \mathrm{O}$ leaving the chamber, and s represents the leaf area [29]. Quantum yield of PSII can be described by:

$$
\Phi_{\mathrm{PSII}}=\frac{F_{m}^{\prime}-F_{s}}{F_{m}^{\prime}}
$$


Table 1. Plains and Ty Ty, GA weather data for peanut research grown in 2018 and 2019.

\begin{tabular}{|c|c|c|c|c|c|}
\hline \multirow{3}{*}{ Location } & \multirow{3}{*}{ Year } & \multirow{3}{*}{ Month } & \multicolumn{2}{|c|}{ Temperature $^{\mathrm{a}}$} & \multirow{2}{*}{ Rainfall } \\
\hline & & & Maximum & Minimum & \\
\hline & & & \multicolumn{2}{|c|}{$\mathrm{C}$} & $\mathrm{cm}$ \\
\hline \multirow[t]{14}{*}{ Plains } & 2018 & April $^{\mathrm{b}}$ & $22.9^{c}$ & 11.2 & 7.2 \\
\hline & & May & 29.2 & 17.9 & 20.2 \\
\hline & & June & 31.8 & 20.7 & 12.5 \\
\hline & & July & 32 & 21.6 & 14.1 \\
\hline & & August & 31.4 & 20.9 & 10 \\
\hline & & September & 32.7 & 21.1 & 8.1 \\
\hline & & October & 28.4 & 16.7 & 16.9 \\
\hline & 2019 & April & 26.6 & 11.5 & 3.5 \\
\hline & & May & 31.4 & 18.4 & 4.0 \\
\hline & & June & 32.7 & 20.9 & 3.7 \\
\hline & & July & 33 & 21.5 & 18.5 \\
\hline & & August & 33 & 21.9 & 10.2 \\
\hline & & September & 33.8 & 19.9 & 0.1 \\
\hline & & October & 28 & 15.8 & 12.1 \\
\hline \multirow[t]{12}{*}{ Ty Ty } & 2018 & May & 30.4 & 18.7 & 34.1 \\
\hline & & June & 32.8 & 21.6 & 33 \\
\hline & & July & 32.5 & 22.3 & 52.2 \\
\hline & & August & 32.4 & 21.9 & 36.1 \\
\hline & & September & 33.1 & 21.8 & 3.7 \\
\hline & & October & 31.3 & 19.9 & 0 \\
\hline & 2019 & May & 31.9 & 19.1 & 4.4 \\
\hline & & June & 32.2 & 21.2 & 14.7 \\
\hline & & July & 33.3 & 21.8 & 8.8 \\
\hline & & August & 33.3 & 22.5 & 21.5 \\
\hline & & September & 33.3 & 20.1 & 0.4 \\
\hline & & October & 34.3 & 20.1 & 0 \\
\hline
\end{tabular}

${ }^{a}$ Temperature is averaged across the entire month and rainfall is total amount. ${ }^{b}$ Data collection began at $1^{\text {st }}$ planting date and terminated on final harvest. ${ }^{c}$ Weather data from University of Georgia Weather Network.

where $F_{m}^{\prime}$ represents the maximum fluorescence yield of PSII and $F_{s}$ represents the minimum fluorescence yield of PSII [29]. ETR is determined by:

$$
\mathrm{ETR}: \Phi_{\mathrm{PSII}} f Q \alpha_{\text {leaf }}
$$

where $\Phi_{\text {PSII }}$ represents the quantum yield of PSII, $f$ is the fraction of photons going to PSII, and $\alpha_{\text {leaf }}$ represents absorption at measurement wavelengths [29]. Finally, the stomatal conductance to water vapor is represented as GSW and is 
calculated by:

$$
\frac{2}{\left(\frac{1}{g_{t w}}-\frac{1}{g_{b w}}\right)+\sqrt{\left(\frac{1}{g_{t w}}-\frac{1}{g_{b w}}\right)^{2}+\frac{4 K}{(K+1)^{2}}\left(2 \frac{1}{g_{t w}}-\frac{1}{g_{b w}}\right) \frac{1}{g_{b w}}}}
$$

where $g_{t w}$ is the total conductance to water vapor, $g_{b w}$ is the boundary layer conductance to water vapor, and $K$ is the stomatal ratio [29].

The gas analyzer was equipped with a MultiPhase Flash ${ }^{\mathrm{TM}}$ Fluorometer set to control the flow rate to leaf chamber at $400 \mu \mathrm{mol} \cdot \mathrm{s}^{-1}$, temperature set at leaf temperature, and set to measure $2 \mathrm{~cm}^{2}$ of the clamped leaf. Readings were taken within 2 hours of solar noon in full sun conditions, between growth stages of V3 to R1 in 2018, and V3 to V6 in 2019 [30]. This measurement timing was chosen as ETR rates are at maximum rate and stability [31]. Physiological data collection readings were collected 2 minutes after leaf chamber was clamped onto the outermost, fully expanded top leaf, or after measured parameters were stabilized (Table 2). Stand counts from 1 of row were taken twice in 2018 and three times

Table 2. Physiological data collection timings in 2018 and 2019 for peanut at Plains and Ty Ty, GA.

\begin{tabular}{|c|c|c|c|c|c|c|c|c|}
\hline \multirow{2}{*}{ Location } & \multirow{2}{*}{ Year } & \multirow{2}{*}{ Measurement ${ }^{\mathrm{a}}$} & \multicolumn{2}{|c|}{ Planting date $1^{\mathrm{b}}$} & \multicolumn{2}{|c|}{ Planting date 2} & \multicolumn{2}{|c|}{ Planting date 3} \\
\hline & & & Date & $\mathrm{GDD}^{\mathrm{c}}$ & Date & GDD & Date & GDD \\
\hline \multirow[t]{9}{*}{ Plains } & 2018 & 1 & $5 / 11$ & 375 & $5 / 14$ & 282 & $6 / 1$ & 493 \\
\hline & & 2 & $5 / 12$ & 404 & $5 / 17$ & 356 & $6 / 5$ & 599 \\
\hline & & 3 & $5 / 14$ & 456 & $5 / 19$ & 410 & $6 / 7$ & 654 \\
\hline & & 4 & $5 / 17$ & 530 & $6 / 1$ & 750 & $6 / 24$ & 1159 \\
\hline & & 5 & $6 / 1$ & 868 & $6 / 5$ & 857 & $6 / 25$ & 1192 \\
\hline & 2019 & 1 & $5 / 1$ & 252 & $5 / 14$ & 329 & $5 / 24$ & 284 \\
\hline & & 2 & $5 / 6$ & 372 & $5 / 15$ & 346 & $5 / 28$ & 422 \\
\hline & & 3 & $5 / 7$ & 395 & $5 / 16$ & 367 & $5 / 29$ & 455 \\
\hline & & 4 & $5 / 14$ & 556 & $5 / 21$ & 507 & $6 / 3$ & 614 \\
\hline \multirow[t]{9}{*}{ Ty Ty } & 2018 & 1 & $5 / 4$ & 389 & $5 / 16$ & 490 & $5 / 19$ & 332 \\
\hline & & 2 & $5 / 5$ & 413 & $5 / 18$ & 544 & $5 / 20$ & 357 \\
\hline & & 3 & $5 / 7$ & 459 & $5 / 19$ & 575 & $5 / 22$ & 409 \\
\hline & & 4 & $5 / 10$ & 537 & $5 / 22$ & 653 & $5 / 25$ & 494 \\
\hline & & 5 & $5 / 16$ & 704 & $5 / 25$ & 738 & $5 / 30$ & 631 \\
\hline & 2019 & 1 & $4 / 27$ & 251 & $5 / 6$ & 271 & $5 / 22$ & 361 \\
\hline & & 2 & $4 / 28$ & 267 & $5 / 7$ & 295 & $5 / 23$ & 390 \\
\hline & & 3 & $4 / 29$ & 306 & $5 / 8$ & 322 & $5 / 24$ & 420 \\
\hline & & 4 & $5 / 6$ & 487 & $5 / 15$ & 485 & $5 / 30$ & 624 \\
\hline
\end{tabular}

${ }^{\mathrm{a}} \mathrm{G}$ as exchange and fluorescence measurements recorded using the LI-6800 infrared gas analyzer. ${ }^{\mathrm{b}} \mathrm{Planting}$ dates for Plains were April $20^{\text {th }}$, May $3^{\text {rd }}$, May $14^{\text {th }}$; and April $17^{\text {th }}$, May $1^{\text {st }}$, May $14^{\text {th }}$, respectively for 2018 and 2019. Planting dates in Ty Ty were April $9^{\text {th }}$, April $25^{\text {th }}$, May $8^{\text {th }}$; and April $12^{\text {th }}$, April $25^{\text {th }}$, May $9^{\text {th }}$, respectively for 2018 and 2019. 'Abbreviations: number of growing degree days, GDD. 
in 2019. Plant width was collected by measuring the widest leaf-tip to leaf-tip of the plant, with 3 plants per plot. Inversion of each PD was determined by the Hull-Scrape Method described in Williams and Drexler [32]. Overall, there were 2208 to 2522 GDD accumulated across experimental planting dates and years. After several days of drying time, peanut pod yield was harvested using a small plot combine.

Data were subjected to analysis of variance (ANOVA) appropriate for the seed germination rate [2] by herbicides [3] by planting dates [3] in a factorial arrangement. ANOVA procedures were conducted using PROC GLIMMIX in SAS University Edition [33]. Means for the significant effects and interactions were separated using Tukey-Kramer HSD set at an $\mathrm{P}<0.05$. Data was analyzed by year, location, planting date (PD), and measurement GDD's for seed germination rate, herbicide treatments, and their interactions.

\section{Results and Discussion}

Significant herbicide by year interactions occurred, preventing the data from being analyzed across years. Therefore, data are presented across herbicide treatment and germination rate by GDD by PD for each year (Figure 1 and Figure 2). A total of 4 (2019) or 5 (2018) measurements per PD were taken from growth stages V3 to R1 for each experiment.

Net Photosynthesis. Differences were first noted for PD 1 at 404 GDD in that flumioxazin treated plants had a higher $A_{\text {net }}$ than the NTC, yet both were not different than the diclosulam treated plants in Plains (Figure 1). Differences were noted at the 456 GDD measurement in which flumioxazin treated plants from low germinating seed had a lower photosynthetic rate compared to the flumioxazin treated and diclosulam treated high germination seed plants. The remaining combinations were not different. Next, PD 3 only had differences at 465 GDD in that the flumioxazin treated plants noted a higher $A_{\text {net }}$ than the other herbicides. This was also noted in herbicide by germination interactions. The flumioxazin treated plants from low germinating seed were higher than the diclosulam treated plants from high germinating seed and the NTC low germinating seed plants. All remaining treatments were not different.

Differences were noted at 459 GDD of PD 1 in that the flumioxazin treated plants were higher than the diclosulam treated plants, yet the NTC was not different from either herbicide treatment. This was also noted in the herbicide by germination interactions in which the flumioxazin treated high germination seed plants noted a higher $A_{\text {net }}$ compared to the diclosulam treated plants with high germination, while both treatments were not different from any other combination. Additional $A_{\text {net }}$ differences for the 2018 season in Ty TY were noted at 357 GDD of PD 3 in which the diclosulam treated plants were lower than the flumioxazin treated plants, while the NTC was not different from either herbicide treatment.

Finally, in 2019, PD 1 noted differences at 252 GDD in that the NTC plants had a higher $A_{\text {net }}$ than the diclosulam treated plants, while the flumioxazin 
2018

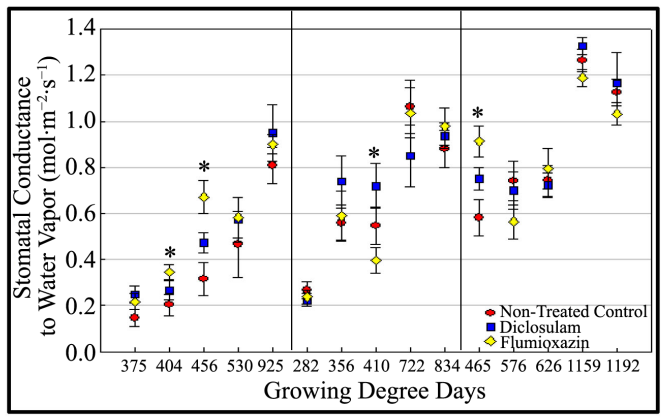

(a)

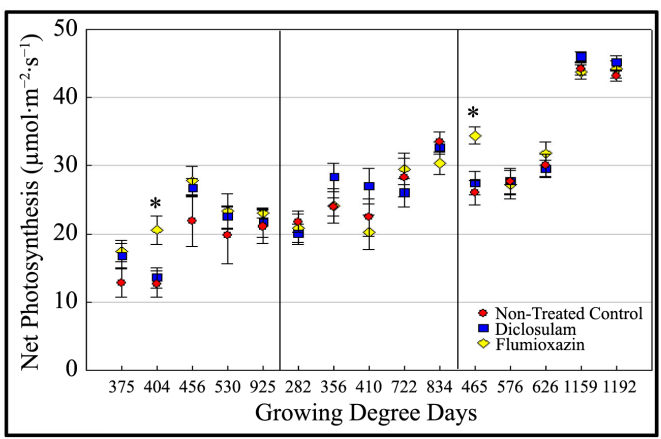

(c)

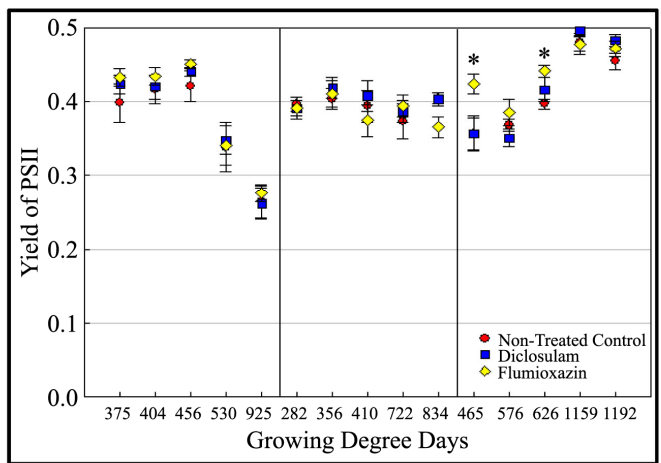

(ae)

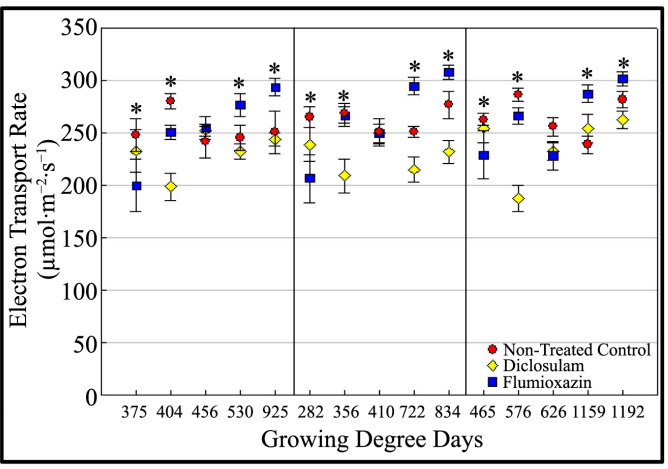

(g)
2019

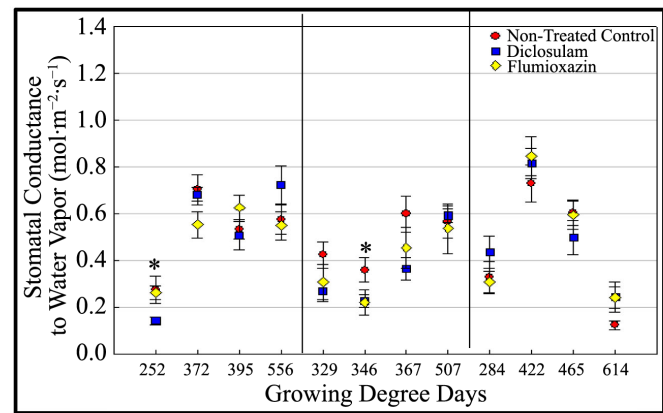

(b)

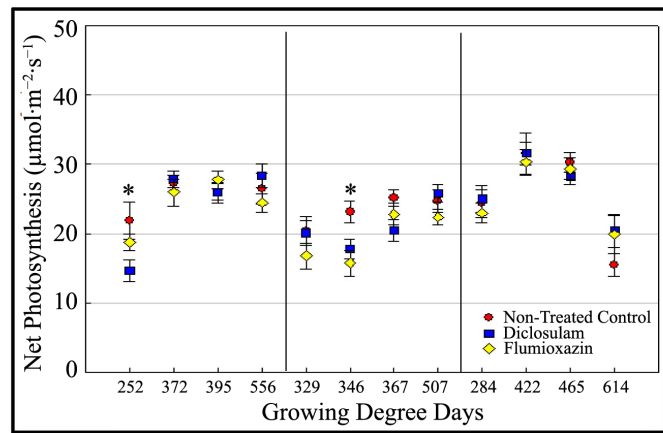

(d)

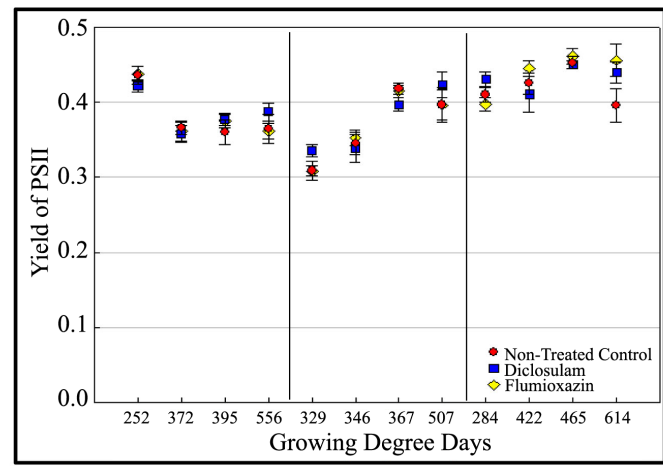

(f)

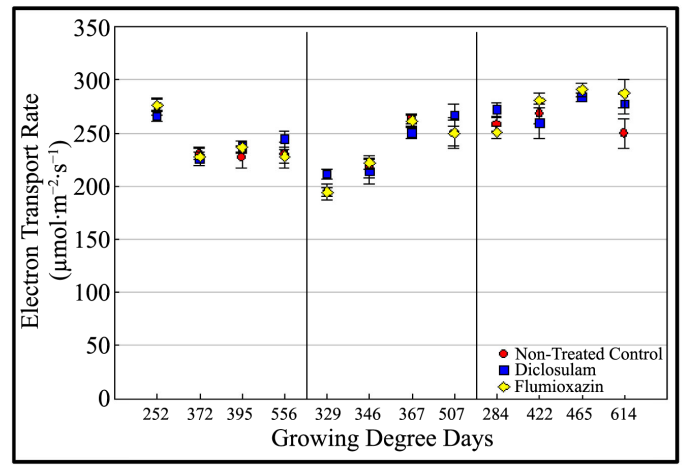

(h)

Figure 1. The response of stomatal conductance to water vapor $\left(\mathrm{g}_{\mathrm{s}}\right)$, net photosynthesis $\left(\mathrm{A}_{\text {net }}\right)$, quantum yield of photosystem II $\left(\Phi_{\mathrm{PSII}}\right)$, and electron transport rate (ETR) during the 2018 and 2019 growing season in Plains, GA. The asterisk indicates significant differences between the treatments at an alpha of 0.05 according to Tukey's HSD. The solid lines indicate each respective planting date with the first being on the left, second PD being in the middle, and the third planting date on the right. 
2018

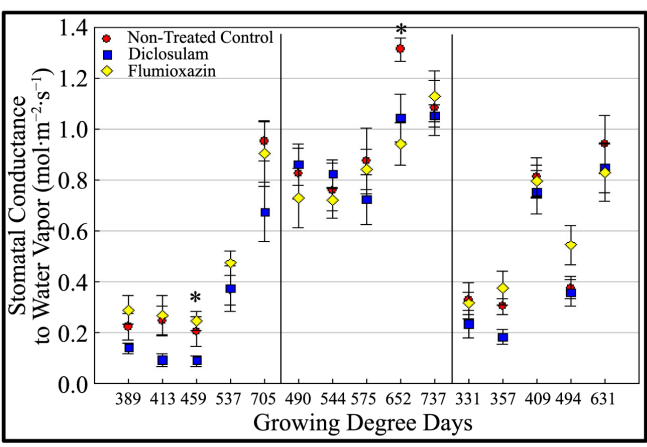

(a)

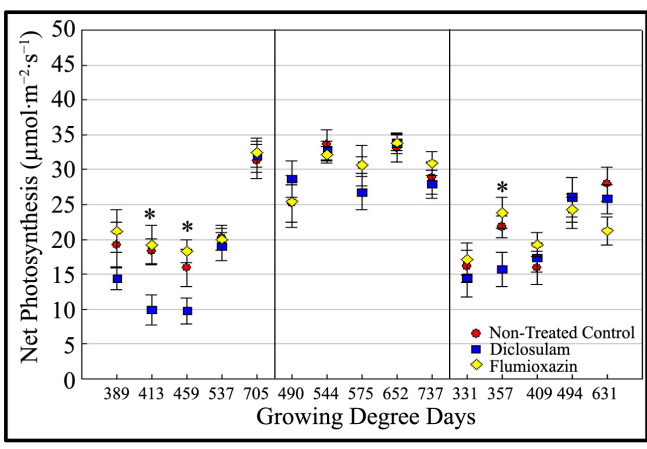

(c)

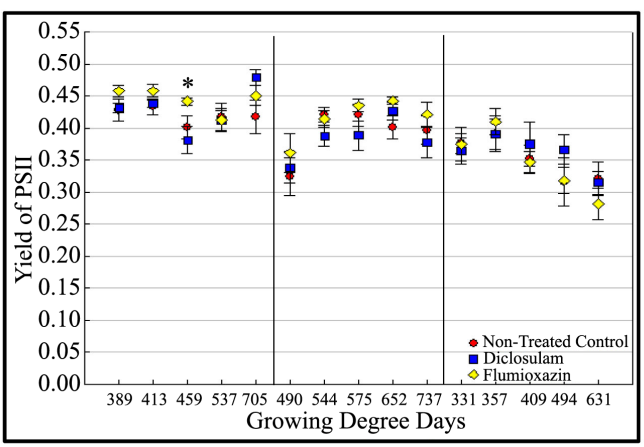

(e)

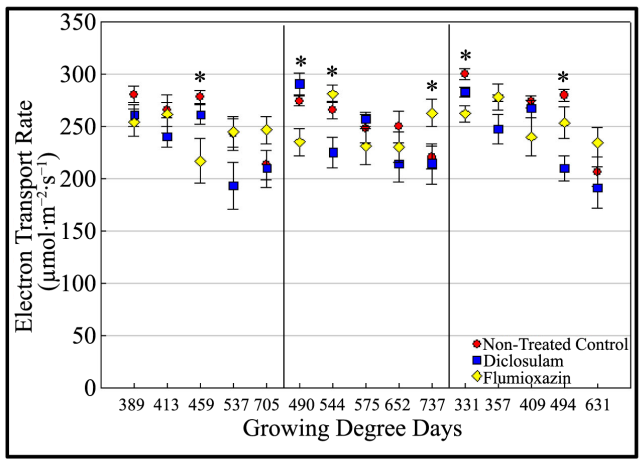

(g)
2019

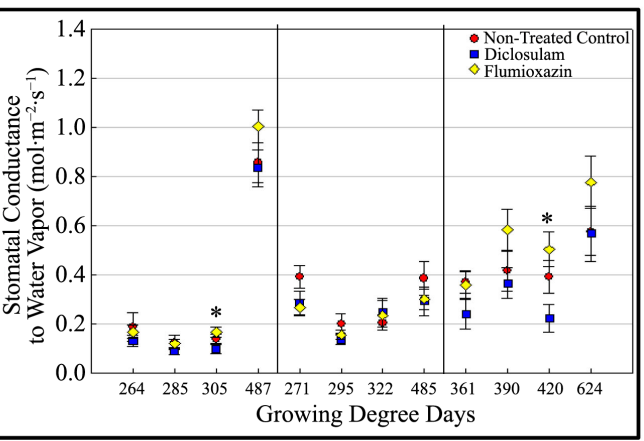

(b)

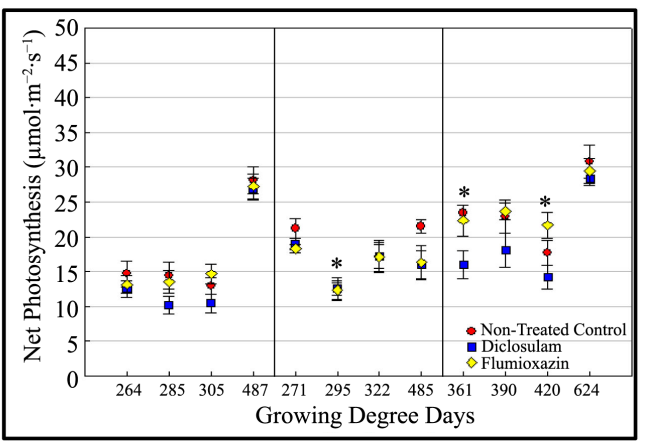

(d)

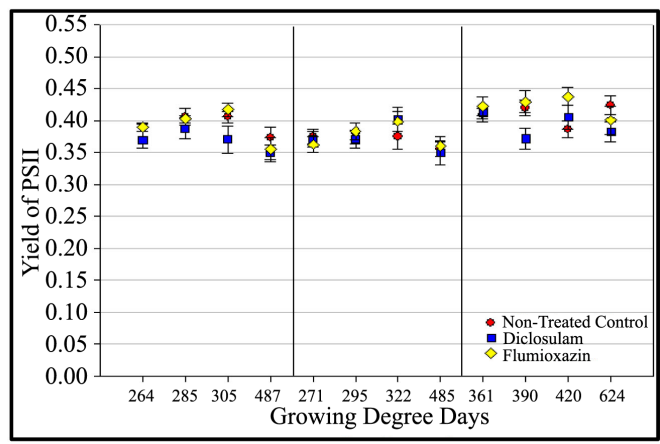

(f)

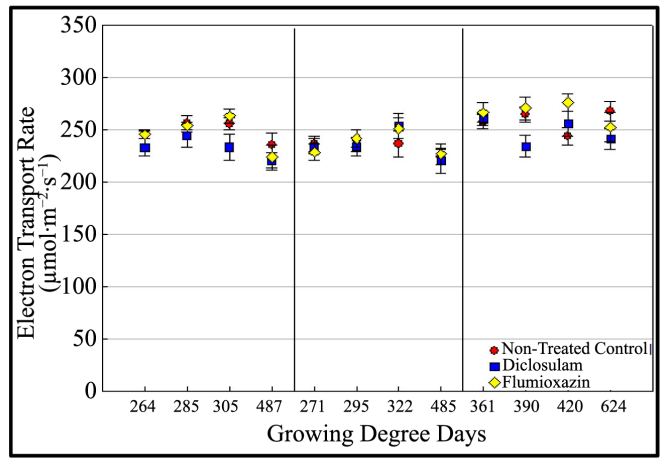

(h)

Figure 2. The response of stomatal conductance to water vapor $\left(\mathrm{g}_{\mathrm{s}}\right)$, net photosynthesis $\left(\mathrm{A}_{\text {net }}\right)$, quantum yield of photosystem II $\left(\Phi_{\mathrm{PSII}}\right)$, and electron transport rate (ETR) during the 2018 and 2019 growing season in Ty Ty, GA. The asterisk indicates significant differences between the treatments at an alpha of 0.05 according to Tukey's HSD. The solid lines indicate each respective planting date with the first being on the left, second PD being in the middle, and the third planting date on the right. 
treated plants were not different from either in Plains (Figure 2). Differences were also noted at $372 \mathrm{GDD}$ in that the high germination plants noted a higher photosynthetic rate compared to the low germination plants. Plant date 2 at 346 GDD indicated differences in the NTC plants had a higher $A_{\text {net }}$ compared to the flumioxazin treated plants, while the diclosulam treated plants were not different from either.

At Ty Ty, for PD 2, after 271 GDD's there were differences in herbicide treatment, germination, and their interactions during the 2019 growing season (Figure 1). First, the NTC plants were higher than the flumioxazin treated plants, while the diclosulam treated plants were not different from either. The high germinating seed plants had a higher $A_{\text {net }}$ compared to the low germinating seed plants. The interaction difference noted was NTC on high germinating plants were higher than all other treatment combinations. The final $A_{\text {net }}$ difference was noted with the flumioxazin treated plants were higher than the diclosulam treated plants, while the NTC were not different from either at 420 GDD of PD 3.

Quantum Yield of Photosystem II. In 2018, quantum yield of PSII was affected at 456 GDD of PD 1 in which both germination and herbicide by germination differences were indicated at the Plains location (Figure 1). The flumioxazin treated and NTC low germination plants had a significantly higher PSII rate when compared to the NTC high vigor plants, while other germination by herbicides were not different $(P=0.028$ and 0.046 , respectively). Germination differences were noted at $925 \mathrm{GDD}$ in which the plants from lower germinating seed indicated a higher PSII yield than the lower germination plants. During PD 3, the 626 GDD measurement indicated the flumioxazin treated plants had a higher PSII yield compared to the NTC, yet both herbicide treatments were not different than the diclosulam treated plants.

In 2018, differences in quantum yield of PSII were noted for PD 1 at 413 GDD in that the high germinating seed plants were higher than plants from low germinating seed, while indicating herbicide by germination differences as well in Ty Ty (Figure 2). High germinating seed plants treated with flumioxazin indicated a higher yield of PSII compared to the NTC low germinating seed plants, while all other combinations were not different from each other. Differences at 459 GDD were also noted with the flumioxazin treated plants being higher in PSII yield compared to the diclosulam treated plants, while the NTC plants were not different from either herbicide.

During the Plains 2019 growing season, differences were noted at the 395 GDD in which the flumioxazin treated high germinating seed plants, along with the NTC and diclosulam low germinating seed plants, had a higher PSII yield compared to the NTC high germinating seed plants (Figure 1). The diclosulam treated plants from high germinating seed and flumioxazin treated plants from low germinating seed were not different from any treatment. In 2019, differences were only noted at 487 GDD of PD 1, in that the high germination seed plants indicated a higher PSII yield compared to the low germination seed plants in Ty 
Ty (Figure 2).

Electron Transport Rate. In 2018, the ETR rates in PD 1 at 375 GDD were different in that the plants from low germinating seed had a higher ETR compared to the high germinating seed plant rates for Plains (Figure 1). This translated into germination by herbicide interactions in that the high germinating seed plants treated with diclosulam had a lower ETR from all other treatment combinations and germination rates, except for the flumioxazin treated plants from low germinating seed. Differences were also recorded at 404 GDD of PD 1 with herbicide treatment differences. The flumioxazin treated plants indicated a lower ETR than the other herbicide treatments. This also translated into germination by herbicide interactions, which is described in Table 3. Finally, at 925 GDD, differences were noted with herbicides, germination rates, and interactions. As with the 530 GDD measurement, the diclosulam treated plants were higher than the other herbicide treatments. In addition, the high germination plants had a higher ETR than the plants from lower germination seed. The herbicide by germination interactions are noted in Table 3. The ETR at Plains for PD 2 showed treatment differences in that the NTC plants had a higher ETR than the diclosulam treated plants, yet both were not different than the flumioxazin treated plants at $282 \mathrm{GDD}$. Herbicide treatment by germination rate interactions is indicated in Table 3. At 356 GDD of PD 2, treatment and treatment by germination interactions were noted in that NTC and diclosulam treated plants had a higher ETR compared to the flumioxazin treated plants. Flumioxazin treated plants had a lower ETR compared to the other herbicide and germination interactions. Differences were noted for all herbicides, germination rates, and interactions at 722 GDD of PD 2 in Plains. All herbicide treatments were different from, while the plants from low germinating seed had a higher ETR than the plants from high germinating seed. The diclosulam treated plants with low germination were different from all treatment and germination rates except for the diclosulam treated plants form high germinating seed. Diclosulam treated plants from both germination rates were significantly higher than the flumioxazin treated plants from high germination seed. Finally, at 834 GDD of PD 2, all treatments were different from each other, with the flumioxazin treated plants indicating a lower ETR than the other herbicide treated plants. At the 576 GDD measurement of plant date 3, the flumioxazin treated plants recorded a lower ETR than all other treated plants. Herbicide by germination interactions were significant in that the flumioxazin treated plants from low germinating seed were different from all combinations, except for the flumioxazin treated plants from the high germinating seed. The flumioxazin treated plants from high germination seed were also not different from the diclosulam treated high germinating seed plants, while being different from the remaining herbicide and germination combinations. Finally, at the 1192 GDD measurement of PD 3, the diclosulam treated plants had a higher ETR compared to the flumioxazin treated plants, yet both were not different from the NTC plants. Herbicide by germination rate interactions indicated that the flumioxazin treated high germinating 
Table 3. The effects on electron transport rate $\left(\mu \mathrm{mol} \cdot \mathrm{m}^{-2} \cdot \mathrm{s}^{-1}\right)$ and stomatal conductance to water vapor $\left(\mathrm{mol} \cdot \mathrm{m}^{-2} \cdot \mathrm{s}^{-1}\right)$ for seedlings established from variable quality GA-16HO seed and treated with different herbicides at Plains, GA for the 2018 growing season.

\begin{tabular}{|c|c|c|c|c|c|}
\hline Plant Date & $\mathrm{GDD}^{\mathrm{b}}$ & Treatment & $\begin{array}{c}\text { Seed } \\
\text { Germination }\end{array}$ & \multicolumn{2}{|c|}{ Estimate $^{c}$} \\
\hline & & & & \multicolumn{2}{|c|}{$\left(\mu \mathrm{mol} \cdot \mathrm{m}^{-2} \cdot \mathrm{s}^{-1}\right)$} \\
\hline 1 & 404 & NTC & Low & 288 & a \\
\hline \multirow[t]{5}{*}{ ETR } & & NTC & High & 273 & a \\
\hline & & Diclosulam & Low & 254 & $\mathrm{ab}$ \\
\hline & & Diclosulam & High & 247 & $a b c$ \\
\hline & & Flumioxazin & High & 205 & $\mathrm{bc}$ \\
\hline & & Flumioxazin & Low & 193 & c \\
\hline 1 & 925 & Diclosulam & High & 304 & a \\
\hline \multirow[t]{5}{*}{ ETR } & & NTC & High & 290 & $\mathrm{ab}$ \\
\hline & & Diclosulam & Low & 284 & $a b$ \\
\hline & & Flumioxazin & Low & 249 & $\mathrm{ab}$ \\
\hline & & Flumioxazin & High & 239 & $\mathrm{bc}$ \\
\hline & & NTC & Low & 212 & c \\
\hline 2 & 282 & Flumioxazin & High & 277 & a \\
\hline \multirow[t]{6}{*}{ ETR } & & NTC & High & 275 & $\mathrm{a}$ \\
\hline & & Diclosulam & Low & 259 & $\mathrm{ab}$ \\
\hline & & NTC & Low & 255 & $\mathrm{ab}$ \\
\hline & & Flumioxazin & Low & 201 & $\mathrm{bc}$ \\
\hline & & Diclosulam & High & 154 & c \\
\hline & & & & \multicolumn{2}{|c|}{$\mathrm{mol} \cdot \mathrm{m}^{-2} \cdot \mathrm{s}^{-1}$} \\
\hline 1 & 456 & Flumioxazin & High & 0.757 & a \\
\hline \multirow[t]{5}{*}{ GSW } & & Flumioxazin & Low & 0.587 & $\mathrm{ab}$ \\
\hline & & Diclosulam & Low & 0.574 & $\mathrm{ab}$ \\
\hline & & NTC & Low & 0.429 & $a b c$ \\
\hline & & Diclosulam & High & 0.372 & $\mathrm{bc}$ \\
\hline & & NTC & High & 0.198 & c \\
\hline
\end{tabular}

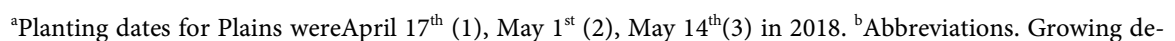
gree days, GDD; Electron transport rate, ETR;stomatal conductance to water vapor, GSW; nontreated control, NTC. ${ }^{c}$ Means with the same letter are not significantly different according to Tukey HSD set at alpha 0.05 .

plants were different from the diclosulam treated plants of both germination rates and the NTC plants from high germinating seed. The other combinations were not different from each other.

Differences were also reported at 490 GDD of PD 2, in which the flumioxazin treated plants were lower than the other two herbicide treatments. These treat- 
ment differences did indicate treatment by germination interactions which are described in Table 4. During Ty Ty's PD 3, differences were indicated at 331 GDD as the flumioxazin treated plants had a lower ETR than the other 2 herbicide treatments. This was also noted in the herbicide by germination interactions in which the flumioxazin treated low germinating plants were different from all combinations, except the flumioxazin treated plants from high germinating seed. The flumioxazin treated high germination plants were not different from any herbicide and germination rate combination. No ETR differences were noted in Plains during the 2019 growing season (Figure 1). The only differences noted in Ty Ty during the 2019 growing season were PD 1 at 487 GDD in which the high germinating plants noted a higher ETR compared to the lower germination plants (Figure 2).

Stomatal Conductance to Water Vapor. During the 2018 growing season, Stomatal conductance to water vapor differences were noted at 404 GDD of Plains PD 1, with the flumioxazin treated plants having a higher GSW than the NTC, yet the diclosulam treated plants were not different from either treatment (Figure 1). These differences were also noted at 456 GDD of PD 1, but the differences translated into herbicide by germination differences also. These differences are described in Table 3. The Plains PD 3 measurement at 465 GDD noted herbicide and herbicide by germination interactions. The flumioxazin treated plants noted a higher GSW than the NTC plants, yet the diclosulam treated plants were not different from either. The flumioxazin treated plants from low germinating seed had a higher GSW rate than the NTC from high germinating seed. All other treatment and germination combinations were not different from each other.

Furthermore, differences were reported for Ty Ty's GSW at PD 1 at 459 GDD in that the flumioxazin treated plants had a higher rate than the diclosulam treated plants, while the NTC plants were not different from either for the 2018 growing season (Figure 2). Interaction differences indicated the diclosulam treated plants from high germinating seed were lower than the flumioxazin treated plants from high germinating seed, yet both were not different from all

Table 4. Herbicide treatment by seedling germination interactions of Ty Ty, Georgia planting date 2 at $490 \mathrm{GDD}^{\mathrm{a}}$ for ETR of the 2018 growing season.

\begin{tabular}{ccc}
\hline Treatment & Seed germination & Estimate $\left(\mu \mathrm{mol} \cdot \mathrm{m}^{-2} \cdot \mathrm{s}^{-1}\right)$ \\
\hline Diclosulam & High & $313^{\mathrm{ab}}$ \\
NTC & Low & $281^{\mathrm{ab}}$ \\
Diclosulam & Low & $269^{\mathrm{abc}}$ \\
NTC & High & $268^{\mathrm{abc}}$ \\
Flumioxazin & Low & $249^{\mathrm{bc}}$ \\
Flumioxazin & High & $221^{\mathrm{c}}$ \\
\hline
\end{tabular}

${ }^{a}$ Abbreviations. Growing degree days, GDD; nontreated control, NTC. ${ }^{b}$ Means with the same letter are not significantly different according to Tukey HSDset at alpha 0.05 . 
other herbicide and germination combinations. Herbicide differences were also noted at 357 GDD of PD 3 in which the flumioxazin treated plants were higher than the diclosulam treated plants, while the NTC plants were not different from either. The Plains 2019 growing season noted differences at 252 GDD of PD 1 in which the NTC and flumioxazin treated plants indicated a higher GSW than the diclosulam treated plants (Figure 1).

In Ty Ty during the 2019 growing season, GSW differences were noted at 305 GDD of PD 1 as the flumioxazin treated plants were higher than the diclosulam treated plants, yet the NTC were not different from either (Figure 2). This was also noted in the herbicide by germination interactions in which the flumioxazin treated plants from low germinating seed were higher than the diclosulam treated plants of both germination rates. The final differences were at 420 GDD of PD 3, in which the flumioxazin treated plants noted a higher GSW compared to the diclosulam treated plants, while the NTC plants were not different from either.

Stand Counts and Yield: Stand counts, plant width, and crop yield were also recorded and analyzed. Plant width in Plains for PD 3 in 2019 noted a difference as the NTC plants were wider than the flumioxazin treatment, with the diclosulam treated plants were not different from either herbicide treated plants. In 2018 and 2019, stand count and yield had no differences noted. Yield for the 2018 and 2019 growing seasons are described in Table 5. Though physiological differences were noted throughout both seasons, no trend was noted, and injury was transient.

In 2019, stand counts were unaffected by herbicide treatments at the Ty Ty location. Plant widths in 2019 were affected in PD 2 and 3. For plant date 2, flumioxazin was different than the remaining treatments by causing some stunting. Plant date 3 recorded that only the NTC was higher than flumioxazin, as both diclosulam and flumioxazin caused stunting. Yields for each PD noted no differences for both years, indicating that though some injury may be seen early in the growing season, the injury is transient. These data may differ from peanut grown under non-irrigated conditions, warranting to further this study under non-irrigated conditions to collect data for Georgia growers who may not use irrigation.

Physiological measurements at multiple planting times have been studied by Virk et al. [34] and noted $A_{\text {net }}$ to be within 15 and $25 \mu \mathrm{mol} \cdot \mathrm{m}^{-2} \cdot \mathrm{s}^{-1}$ while ETR was within 97 and $267 \mu \mathrm{mol} \cdot \mathrm{m}^{-2} \cdot \mathrm{s}^{-1}$ for peanut. Peanut physiological measurements recorded were within or near Virk et al. [34] findings validating each parameter. Photosynthesis is a process utilized by plants to grow and produce glucose and oxygen from water and carbon dioxide [35], driven by photosynthetically active radiation (PAR). PAR are light wavelengths between 400 and $700 \mathrm{~nm}$ [36]. Virk et al. [34] determined the physiological effects of multiple planting dates on peanut photosynthetic efficiency of first true leaves. The investigators noted that net peanut plant photosynthesis was unaffected by PD for any cultivar tested, though numerous photosynthetic reactions were affected. Planting date affected 
Table 5. Peanut seed pod yield from 2018 and 2019 growing seasons in Ty Ty and Plains Georgia.

\begin{tabular}{|c|c|c|c|c|c|c|}
\hline \multirow[t]{2}{*}{ Location } & \multirow[t]{2}{*}{ Year } & \multirow[t]{2}{*}{ Treatment $^{\mathrm{a}}$} & \multirow{2}{*}{$\begin{array}{c}\text { Seed } \\
\text { Germination }\end{array}$} & $\begin{array}{l}\text { Planting } \\
\text { Date } 1^{\text {b }}\end{array}$ & $\begin{array}{c}\text { Planting } \\
\text { Date } 2\end{array}$ & $\begin{array}{c}\text { Planting } \\
\text { Date } 3\end{array}$ \\
\hline & & & & \multicolumn{3}{|c|}{$\mathrm{kg} / \mathrm{ha}$} \\
\hline \multirow[t]{12}{*}{ Plains } & 2018 & Diclosulam & High & 6136 & 6285 & 5743 \\
\hline & & Diclosulam & Low & 6281 & 5164 & 5343 \\
\hline & & Flumioxazin & High & 6715 & 6396 & 6221 \\
\hline & & Flumioxazin & Low & 6130 & 5003 & 6208 \\
\hline & & NTC & High & 6376 & 5510 & 5938 \\
\hline & & NTC & Low & 6270 & 5523 & 6250 \\
\hline & 2019 & Diclosulam & High & 3936 & 5545 & 2432 \\
\hline & & Diclosulam & Low & 4107 & 5878 & 2437 \\
\hline & & Flumioxazin & High & 4303 & 5551 & 2450 \\
\hline & & Flumioxazin & Low & 4283 & 6140 & 2223 \\
\hline & & NTC & High & 3340 & 5866 & 2193 \\
\hline & & NTC & Low & 3598 & 5247 & 2450 \\
\hline \multirow[t]{12}{*}{ Ty Ty } & 2018 & Diclosulam & High & 6449 & 6971 & 7026 \\
\hline & & Diclosulam & Low & 6473 & 6826 & 6423 \\
\hline & & Flumioxazin & High & 7083 & 7424 & 6813 \\
\hline & & Flumioxazin & Low & 6709 & 6401 & 6415 \\
\hline & & NTC & High & 7473 & 6948 & 7449 \\
\hline & & NTC & Low & 6831 & 6749 & 7140 \\
\hline & 2019 & Diclosulam & High & 6483 & 6808 & 6141 \\
\hline & & Diclosulam & Low & 6172 & 7008 & 6398 \\
\hline & & Flumioxazin & High & 6265 & 6979 & 6356 \\
\hline & & Flumioxazin & Low & 6211 & 6708 & 6310 \\
\hline & & NTC & High & 6112 & 6949 & 5646 \\
\hline & & NTC & Low & 6242 & 6786 & 5660 \\
\hline
\end{tabular}

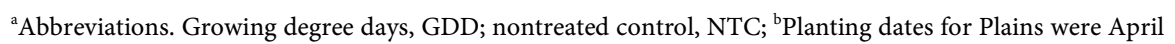
$20^{\text {th }}(1)$, May $3^{\text {rd }}(2)$, May $14^{\text {th }}(3)$; and April $17^{\text {th }}(1)$, May $1^{\text {st }}(2)$, May $14^{\text {th }}(3)$, respectively for 2018 and 2019. Planting dates in Ty Ty were April $9^{\text {th }}(1)$, April $25^{\text {th }}(2)$, May $8^{\text {th }}(3)$; and April $12^{\text {th }}(1)$, April $25^{\text {th }}(2)$, May $9^{\text {th }}$ (3), respectively for 2018 and 2019.

parameters such as electron transport rate and stomatal conductance to water vapor due to the plant being at different growth stages as temperatures fluctuated.

During both growing seasons, rainfall events occurred during, or shortly after peanut emergence. As the rain impacted the ground, splash bounced onto green leaf matter, while also carrying flumioxazin. The flumioxazin would then cause necrotic and chlorotic injury on the leaves. This injury was noted periodically to occur on the measured leaf, partially causing a reduction in photosynthesis. This 
is supported by Garry et al. [37] in which the investigators noted a reduction in photosynthesis as necrosis was noted on pea (Pisum sativum L.) leaves. It was not directly proportional to injury, though, in that photosynthesis was not noted to decrease as necrotic injury increased. Bigot et al. [38] indicated that as stomatal closure occurred from flumioxazin, photosynthesis was reduced, as well as plant transpiration. The investigators also noted that $\Phi_{\text {PSII }}$ was significantly reduced in grapevine leaves, due to alterations of other photochemicals, causing a higher number of closed PSII reaction centers. Though numerous physiological injuries occur, this injury was noted to not cause yield loss or reduced fiber quality in cotton [23]. This supports the findings of this study in that peanut yield for all treatments, with respect to planting dates and locations, were not different in each yr.

Other crops have shown sensitivity to POST flumioxazin applications. Wilcut et al. [23] reported rainfall splash bouncing up to $15 \mathrm{~cm}$ reaching green plant matter, did not cause yield loss or fiber quality reduction in cotton. Bigot et al. [38] performed a study measuring the physiological response of grapevine (Vitis vinifera L.) to flumioxazin applications. The investigators noted that net photosynthesis rate was significantly decreased when applied beginning at only one $d$ after soil application, including plant death. Other PPO herbicides have been shown to cause injury when plants are subjected to adverse conditions during emergence. Miller et al. [39] reported that soybean sustained injury from saflufenacil when emerging during cold, wet conditions. These types of injury are common among crops that have had flumioxazin applied to them.

The 2018 and 2019 growing seasons had drastically different weather events which may have contributed to the varying measurements between yr. The increased rainfall during emergence in 2018 played a role in causing increased injury in the 2018 season, and not in the 2019 season as previously discussed. Though numerous differences were noted, no season long trend of injury was noted. The physiological injury noted during the measurements was transient and did not impact yield (data not shown). Though growers may see early season injury from flumioxazin in adverse weather conditions, this injury will likely not cause yield reductions.

\section{Acknowledgements}

The Georgia Peanut Commission, National Peanut Board, Georgia Seed Development, Valent U.S.A, Corteva Agriscience, Southwest Georgia Research and Education Center team members, Sidney Cromer.

\section{Conflicts of Interest}

The authors declare no conflict of interest.

\section{References}

[1] National Agricultural Statistics Survey (2019) Crop Production Report. United 
States Department of Agriculture, National Agricultural Statistics Survey, Washington DC.

https://www.nass.usda.gov/Publications/Todays_Reports/reports/crop0919.pdf

[2] National Agricultural Statistics Survey (2019) 2018 Agricultural Chemical Use Survery: Peanuts. United States Department of Agriculture, National Agricultural Statistics Survey, Washington DC.

https://www.nass.usda.gov/Surveys/Guide_to_NASS_Surveys/Chemical_Use/2018_ Peanuts Soybeans Corn/ChemUseHighlights_Peanuts_2018.pdf

[3] Kvien, C.K., Holbrook, C.C., Ozias-Akins, P., Pilon, C., Culbreath, A.K. and Brenneman, T.B. (2019) Peanut Production Guide 2019: Peanut Physiology. University of Georgia Press, Athens.

[4] Canavar, Ö. and Kaynak, M.A. (2010) Growing Degree Day and Sunshine Radiation Effects on Peanut Pod Yield and Growth. African Journal of Biotechnology, 9, 2234-2241.

[5] Boote, K.J., Jones, J.W., Hoogenboom, G., Wilkerson, G.G. and Jagtap, S.S. (1989) PNUTGO V1.02: Technical Documentation. IBSNAT Project, Department of Agronomy and Soil Science, University of Hawaii, Honolulu.

[6] Sundaraj, S., Srinivasan, R., Culbreath, A.K., Riley, D.G. and Pappu, H.R. (2014) Host Plant Resistance against Tomato spotted wilt virus in Peanut and Its Impact on Susceptibility to the Virus, Virus Population Genetics, and Vector Feeding Behavior and Survival. Phytopathology, 104, 202-210. https://doi.org/10.1094/PHYTO-04-13-0107-R

[7] Grey, T.L., Chen, C.Y., Nuti, R., Monfort, W.S. and Cutts III, G. (2017) Characterization of Genotype by Planting Date Effects on Runner-Type Peanut Seed Germination and Vigor Response to Temperature. In: Jimenez-Lopez, J.C., Ed., Advances in Seed Biology, IntechOpen, London, 103-122.

https://doi.org/10.5772/intechopen.70584

[8] Prasad, P.V., Boote, K.J., Thomas, J.M., Allen Jr., L. and Gorbet, D.W. (2006) Influence of Soil Temperature on Seedling Emergence and Early Growth of Peanut Cultivars in Field Conditions. Journal Agronomy Crop Science, 192, 168-177.

[9] Grichar, W.J. and Dotray, P.A. (2012) Weed Control and Peanut Tolerance with Ethalfluralin-Based Herbicide Systems. International Journal of Agronomy, 2012, Article ID: 597434. https://doi.org/10.1155/2012/597434

[10] Everman, W.J., Clewis, S.B., Thomas, W.E., Burke, I.C. and Wilcut, J.W. (2008) Critical Period of Weed Interference in Peanut. Weed Technology, 22, 63-67.

[11] Monfort, W.S., Prostko, E.P., Tubbs, R.S., Harris, G., Abney, M., Porter, W.M. and Kemerait, R. (2019) University of Georgia Peanut Production Quick Reference Guide. University of Georgia Extension Publication, Georgia. http://www.gapeanuts.com/growerinfo/2018_ugapeanutguide.pdf

[12] Grey, T.L., Bridges, D.C., Prostko, E.P., Eastin, E.F., Johnson III, W.C., Vencill, W.K., Brecke, B.J., MacDonald, G.E., Tredaway, J.A., Everest, J.W., Wehtje, G.R. and Wilcut, J.W. (2003) Residual Weed Control with Imazapic, Diclosulam, and Flumioxazin in Southeastern Peanut. Peanut Science, 30, 22-27. https://doi.org/10.3146/pnut.30.1.0005

[13] Grey, T.L., Bridges, D.C. and Eastin, E.F. (2001) Influence of Application Rate and Timing of Diclosulam on Weed Control in Peanut. Peanut Science, 28, 13-19. https://doi.org/10.3146/i0095-3679-28-1-4

[14] Murphree, T.A. (2003) Varietal Tolerance to Diclosulam and Flumioxazin in Texas Peanut. Texas Tech University, Lubbock, 36. 
[15] Karnei, J.R. (2002) Efficacy and Crop Tolerance to Diclosulam. Texas Tech University, Lubbock, 35.

[16] Grichar, W.J., Besler, B.A., Dotray P.A., Johnson III, W.C. and Prostko E.P. (2004) Interaction of Flumioxazin with Dimethenamid or Metolachlor in Peanut. Peanut Science, 31, 12-16. https://doi.org/10.3146/pnut.31.1.0003

[17] Shaner, D.L. (2014) Herbicide Handbook. 10th Edition, Weed Science Society of America, Lawrence, 212-213.

[18] Grossmann, K., Niggweg, R., Christiansen, N., Looser, R. and Ehrhardt, T. (2010) The Herbicide Saflufenacil (Kixor ${ }^{\mathrm{TM}}$ ) Is a New Inhibitor of Protoporphyrinogen IX Oxidase Activity. Weed Science, 58, 1-9. https://doi.org/10.1614/WS-D-09-00004.1

[19] Berger, S., Ferrell, J., Brecke, B., Faircloth, W. and Rowland D. (2012) Influence of Flumioxazin Application Timing and Rate on Cotton Emergence and Yield. Weed Technology, 26, 622-626. https://doi.org/10.1614/WT-D-12-00044.1

[20] Jordan, D.L., Spears, J.F. and Wilcut, J.W. (2003) Tolerance of Peanut to Herbicides Applied Postemergence. Peanut Science, 30, 8-13.

https://doi.org/10.3146/pnut.30.1.0002

[21] Price, A.J., Wilcut, J.W. and Cranmer, J.R. (2004) Physiological Behavior of Root-Absorbed Flumioxazin in Peanut, Ivyleaf Morningglory (Ipomoea hederacea), and Sicklepod (Senna obtusifolia). Weed Science, 52, 718-724.

https://doi.org/10.1614/WS-04-017R

[22] Johnson III, W.C., Prostko, E.P. and Mullinix Jr., B.G. (2006) Phytotoxicity of Delayed Applications of Flumioxazin on Peanut. Weed Technology, 20, 157-163. https://doi.org/10.1614/WT-04-328R.1

[23] Wilcut, J.W., Askew, S.D., Bailey, W.A., Spears, J.F. and Isleib, J.G. (2001) Virginia Market-Type Peanut Cultivar Yield Response to Flumioxazin Preemergence. Weed Technology, 15, 137-140. https://doi.org/10.1614/0890-037X(2001)015[0137:VMTPAH]2.0.CO;2

[24] Askew, S.D., Wilcut, J.W. and Cranmer, J.R. (1999) Weed Management in Peanut with Flumioxazin Preemergence. Weed Technology, 13, 594-598. https://doi.org/10.1017/S0890037X0004625X

[25] English, R.G. (2003) The Basis of Selectivity for Flumioxazin Use in Peanut and Associated Weeds. University of Georgia, Athens, 27p.

[26] Branch, W.D. (2017) Registration of 'Georgia-16HO’ Peanut. Journal of Plant Registrations, 11, 231-234. https://doi.org/10.3198/jpr2016.11.0062crc

[27] Anonymous (2010) Valor SX Herbicide Label. Valent U.S.A. Corporation, Walnut Creek.

[28] Anonymous (2010) Strongarm Herbicide Label. Corteva Agriscience, Wilmington.

[29] Anonymous (2017) Using the LI-6800 Portable Photosynthesis System. Li-COR Biosciences, Lincoln.

https://licor.app.boxenterprise.net/s/6afbbpwybdanht6xrbgwicur4yohpx1n

[30] Boote, K.J. (1982) Growth Stages of Peanut. Peanut Science, 9, 35-40. https://doi.org/10.3146/i0095-3679-9-1-11

[31] Snider, J.L., Collings, G.D., Whitake, J., Perry, C.D. and Chastain, D.R. (2013) The Effect of Water Deficit on Photosynthetic Electron Transport and $\mathrm{Net}_{\mathrm{CO}_{2}}$ Assimilation Rates in Field-Grown Cotton. In: Don Shurley, W., Whitaker, J. and Snider, J.L., Eds., 2012 Georgia Cotton Research-Extension Report, The University of Georgia, Athens, 51-55.

https://secure.caes.uga.edu/extension/publications/files/pdf/AP\%20108_4.PDF. 
[32] Williams, E.J. and Drexler, J.S. (1981) A Non-Destructive Method for Determining Peanut Pod Maturity. Peanut Science, 8, 134-141. https://doi.org/10.3146/i0095-3679-8-2-15

[33] SAS Institute (2020) The SAS University Edition for Windows, Release 9.4. The SAS Institute Inc., Cary.

[34] Virk, G., Pilon, C. and Snider, J.L. (2019) Impact of First True Leaf Photosynthetic Efficiency on Peanut Plant Growth under Different Early-Season Temperature Conditions. Peanut Science, 46, 162-173. https://doi.org/10.3146/PS19-8.1

[35] Arnon, D.I. (1971) The Light Reactions of Photosynthesis. Proceedings of the National Academy of Sciences of the United States of America, 68, 2883-2892. https://doi.org/10.1073/pnas.68.11.2883

[36] Möttus, M., Suley, M., Baret, F., Lopez-Lozano, R. and Reinart, A. (2012) Photosynthetically Active Radiation: Measurement and Modeling. In: Meyers, R.A., Ed., Encyclopedia of Sustainability Science and Technology, Springer, New York, 7970-8000. https://doi.org/10.1007/978-1-4419-0851-3_451

[37] Garry, G., Jeuffroy, M.H., Ney, B. and Tivoli, B. (1998) Effects of Ascochyta Blight (Mycosphaerella pinodes) on the Photosynthesizing Leaf Area and the Photosynthetic Efficiency of the Green Leaf Area of Dried-Pea (Pisum sativum). Plant Pathology, 47, 473-479. https://doi.org/10.1046/j.1365-3059.1998.00259.x

[38] Bigot, A., Fontaine, F., Clément, C. and Vaillant-Gaveau, N. (2007) Effect of the Herbicide Flumioxazin on Photosynthetic Performance of Grapevine (Vitis vinifera L.). Chemosphere, 67, 1243-1251. https://doi.org/10.1016/j.chemosphere.2006.10.079

[39] Miller, R.T., Soltani, N., Robinson, D.E., Kraus, T.E. and Sikkema, P.H. (2012) Soybean (Glycine max) Cultivar Tolerance to Saflufenacil. Canadian Journal of Plant Science, 92, 1319-1328. https://doi.org/10.4141/cjps2012-055 